\title{
Morphotectonic Study of Frontal Siwalik Hills, near Gandhiri, Kangra, Himachal Pradesh, India
}

\author{
Yoginder Singh, A. R. Chaudhri \\ Department of Geology, Kurukshetra University, Kurukshetra, India \\ Email: archaudhri@gmail.com
}

How to cite this paper: Singh, Y. and Chaudhri, A.R. (2020) Morphotectonic Study of Frontal Siwalik Hills, near Gandhiri, Kangra, Himachal Pradesh, India. Open Journal of Geology, 10, 280-300. https://doi.org/10.4236/ojg.2020.104015

Received: February 17, 2020

Accepted: April 5, 2020

Published: April 8, 2020

Copyright () 2020 by author(s) and Scientific Research Publishing Inc. This work is licensed under the Creative Commons Attribution International License (CC BY 4.0).

http://creativecommons.org/licenses/by/4.0/

\section{(c) (i) Open Access}

\begin{abstract}
The densely populated foothill zone of western Himalaya between the Beas river and the Chakki stream in and around Kangra is being critically examined by us considering the seismo-tectonic destructive potential of the 1905 (Mw 7.8) Kangra earthquake which has not been evaluated so far. We use Resourcesat 1: LISS III Ortho satellite imageries and field studies to qualitatively and quantitatively assess the active tectonic setup of the terrain. Quantitative morphotectonic analysis viz. hypsometric integral, drainage basin asymmetry, stream sinuosity index, ratio of valley floor width to valley height, stream length gradient index, basin shape index and mountain front sinuosity index are being evaluated on high resolution digital elevation model. The five sub-drainage basins of the Gandhiri stream, the Sukar stream and the Duhg stream of Kangra district of Himachal Pradesh, India are being morphotectonically analyzed. The value of hypsometric integral, drainage basin asymmetry, stream sinuosity index, ratio of valley floor width to valley height, stream length gradient index, basin shape index and mountain front sinuosity index reveal that the terrain is tectonically active. An active dextral strike slip fault with significant oblique slip component has been inferred and is being named as the Gandhiri Fault. This fault crosses all the five sub-drainage basins and results in multiple stream offsets. The Index of Relative Tectonic Activity (IRAT) has been established for different sub-drainage basins. The study reveals that the terrain near Gandhiri in Kangra district of Himachal Pradesh is seismo-tectonically active and proper building codes should be followed in construction activity.
\end{abstract}

\section{Keywords}

Morphotectonic, Shutter Ridges, Gandhiri Fault, Index of Relative Tectonic Activity (IRAT) 


\section{Introduction}

The Kangra (1905, Mw 7.8) earthquake, along with the Bihar-Nepal earthquake (1934, Mw 8.1), the Assam (1950, Mw 8.4) quake and other recent earthquakes has highlighted the importance of identification of active faults and their characterization so as to comprehend the quantum of seismic vulnerability of the densely populated Himalayan foothill region. As per media reports 20,000 lives were lost in Kangra quake; 12,000 lives were lost in the Bihar-Nepal earthquake and around 5000 people were killed in the Assam earthquake. As per 2011 census of India, the population of Kangra district is more than 1.5 million. There is an urgent need to characterize the tectonic nature of the populated foothill region and to identify the active faults in the terrain which can pose a serious seismic threat. The tectonic activity in the Himalaya is due to the continuous movement of the Indian plate in the northward direction, at an average rate of $50 \mathrm{~mm}$ per year [1]. This has made the foothill terrain a high stress and strain zone. Morphotectonic analysis is being increasingly used to assess the relative impact of tectonic forces and the surface stability in different parts of the terrain spread over a broad region [2]-[16]. The use of geomorphic indices such as the stream length gradient index [17], drainage basin asymmetry [18], hypsometric integral [19], ratio of valley floor width to valley height [20], drainage basin shape [20] [21] and mountain front sinuosity index [20] in active tectonic studies has been successfully demonstrated by numerous researchers including [4] [5] [20] [22] [23] [24] and others. The study area (Figure 1) lies in the frontal Siwalik terrain between the Beas river and the Chakki stream. The NW-SE trending Gandhiri stream drains the frontal Siwalik terrain and runs for the 23 $\mathrm{km}$. The Gandhiri stream crosses the Soan Thrust, where the Quaternary sediments are overlain by the Middle Siwalik subgroup, joins the Beas river in the foothill region. In this study, we attempt to closely examine the terrain near Gandhiri in Kangra district of Himachal Pradesh to identify the active fault present in the region which could facilitate the possible damages in the event of a large magnitude earthquake striking the region. The current study would help built up relevant data required for a comprehensive evaluation of the seismo-tectonics of the region. The main sections in this paper are geological setup, materials and methods, results comprising drainage basin, morphotectonic indices viz. hypsometric integral, drainage basin asymmetry, stream length gradient index, mountain front sinuosity index, stream sinuosity index, basin shape index, valley floor width to valley height ratio and field investigation followed by discussion and conclusion.

\section{Geological Setup}

In the Kangra reentrant, rocks of the Mid-Miocene-Mid-Pleistocene Siwalik foreland group are exposed in the study area. The Middle and Upper Siwalik subgroups are better exposed. The lithostratigraphy of the Siwalik group exposed in the study area is depicted in Table 1 . The active tectonic setup of the terrain 


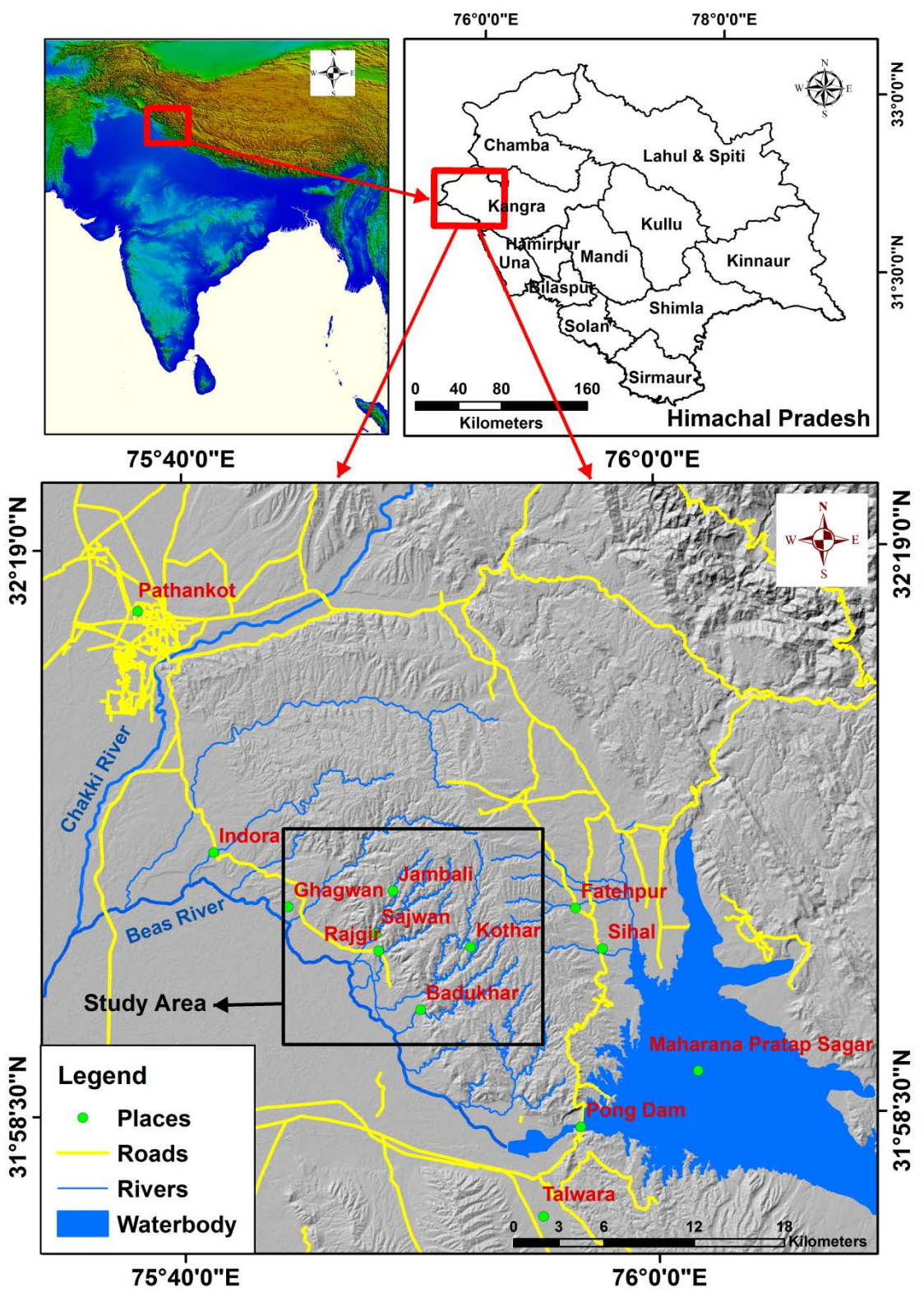

Figure 1. Location map of the study area.

Table 1. Generalized lithostratigraphic succession of the Siwalik Group (modified after [37] [38]).

\begin{tabular}{|c|c|c|}
\hline Group & Subgroup & Lithology \\
\hline \multirow{3}{*}{$\begin{array}{l}\text { Siwalik } \\
\text { Group }\end{array}$} & $\begin{array}{l}\text { Upper Siwalik Subgroup } \\
\text { (Tatrot, Pinjor and Boulder } \\
\text { Conglomerate formations) } \\
\quad(600 \mathrm{~m}-2400 \mathrm{~m})\end{array}$ & $\begin{array}{l}\text { Conglomerates, poorly indurated sandston } \\
\text { and pale-grey and pale-brown sandy clays }\end{array}$ \\
\hline & $\begin{array}{c}\text { Middle Siwalik Subgroup } \\
\text { (Nagri and Dhokpathan formations) } \\
(1400 \mathrm{~m}-2000 \mathrm{~m})\end{array}$ & $\begin{array}{l}\text { Moderately indurated sandstones } \\
\text { and chocolate coloured clays }\end{array}$ \\
\hline & $\begin{array}{c}\text { Lower Siwalik Subgroup } \\
\text { (Kamlial and Chinji formations) } \\
(1300 \mathrm{~m}-1900 \mathrm{~m})\end{array}$ & $\begin{array}{l}\text { Alternating sequence of well indurated } \\
\text { sandstones and purple maroon clays }\end{array}$ \\
\hline
\end{tabular}


between the Beas river and the Chakki stream is poorly understood. In this study, we attempt to quantitatively analyzed the morphotectonic setup of the terrain on the basis of the active tectonic indices viz. stream length gradient index [17], drainage basin asymmetry [18], hypsometric integral [19], ratio of valley floor width to valley height [20], drainage basin shape [20] [21] and mountain front sinuosity [20]. The Bharwain anticline and the Dhinosar syncline comprise the major structural features of the study area. The northward dipping forelimb of the Dhinosar syncline forms a thrust junction with the Quaternary deposits. This thrust has been named as Soan Thrust. The Gandhiri stream (locally termed as Khad) drains the Bharwain anticline. This anticline has numerous minor faults which have developed parallel to sub-parallel to the major thrusting zone of the Himalaya by high oblique convergence rate along the Soan Thrust. The tectonic activity in the Kangra region has been documented by [25]-[36] and others.

The Bharwain anticline and the Dhinosar syncline form the major regional structural features in the area under investigation. The forelimb of the Dhinosar syncline dips towards North direction and is thrusted over the Quaternary deposits in the South. Crustal shortening of the foothill thrust at a rate of $14 \pm 2$ $\mathrm{mm} / \mathrm{yr}$ [39] contributes to the tectonics in the region. Numerous minor faults have developed in parallel to sub-parallel orientation with the major thrusting zones of the Himalaya. In the study area, Middle Siwalik subgroup is represented by $5-7 \mathrm{~m}$ thick massive horizontal beds of sandstone, siltstone, clays and inter-bedded pebbly beds. The outer Himalayan range consists of the Siwalik sequence which is folded and faulted due to fault propagation folding [40]. A shortening about $23 \mathrm{~km}$ since 1.9 to $1.5 \mathrm{Ma}$, across the Siwalik sequence in the Kangra reentrant has been reported [41]. Along the Soan Thrust, crustal shortening rate of $3 \pm 0.3 \mathrm{~mm} / \mathrm{yr}$ and slip rate of $3.3 \pm 0.3 \mathrm{~mm} / \mathrm{yr}$ is observed [33]. This in turn has resulted in accumulation of stress and strain in the terrain surrounding Gandhiri lineament zone. Geological map (Figure 2) has been prepared by field traverse which supports the previous literature and different geological investigations.

\section{Materials and Methods}

The frontal terrain between the Beas river and the Chakki stream is thickly covered by vegetation. Resourcesat 1: LISS III Ortho Satellite Imagery $(24 \mathrm{~m})$ is being used for lineament extraction by visual interpretation and by study of digital elevation model. Band combination and image enhancement tools such as band sharpening, band rationing, edge enhancement, contrast and brightness enhancement etc. have been used for critical terrain evaluation. The Shuttle Radar Topographic Mission (SRTM) based digital elevation model with $30 \mathrm{~m}$ resolution is being used for delineating drainage network and sub-drainage basin with the help of ARCGIS 10.3.1 Software. A terrain model has been prepared in which Resourcesat 1: LISS III satellite imagery is draped over the digital elevation 


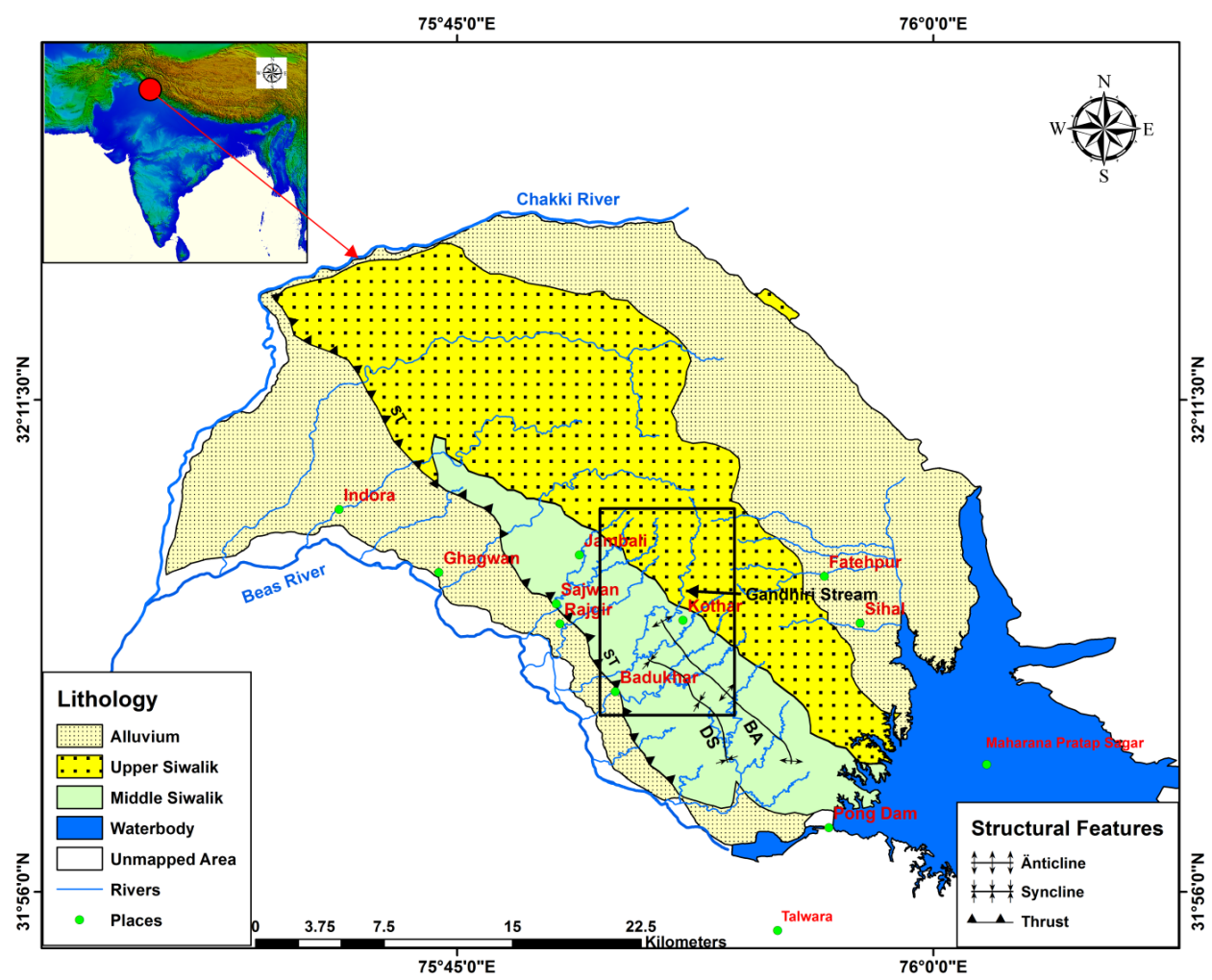

Figure 2. Geological map of the study area (modified after [39] [42] [43] [44]); ST: Soan Thrust; BA: Bharwain Anticline; DS: Dhinosar Syncline.

model. The 3-D model of topographic features reveals the presence of a $3.2 \mathrm{~km}$ long strike slip active fault in the Gandhiri Stream. The fault has a significant oblique slip component. Shutter ridges and offset streams have been observed in the field. Quantitative morphotectonic analysis viz. drainage basin asymmetry, hypsometric integral, valley floor width to valley height ratio, stream length gradient index, stream sinuosity index and mountain front sinuosity index are being evaluated on digital elevation model for five parallel sub-drainage basins to determine the terrain characteristics.

\section{Results}

Resourcesat 1: LISS III false colour composite and true colour Google Earth satellite imagery (Figure 3) of the frontal Himalayan terrain between the Beas river and the Chakki stream indicates the presence of different geomorphic and structural features. A raster layer has been generated by draping satellite imagery over the digital elevation model for the characterization of geomorphic as well as structural lineaments [45]. One of the major lineaments is observed trending in NW-SE direction. Along the lineament a dextral strike slip movement with significant oblique slip component has been recorded. The sinuous Gandhiri stream crosses this lineament at three locations L1, L2 and L3. The stream is offset at all these three locations. The length of stream offset are $330 \mathrm{~m}, 140 \mathrm{~m}$ and $535 \mathrm{~m}$ (Figures 4(a)-(f)). At the site of offsets shutter ridges are very well developed. 


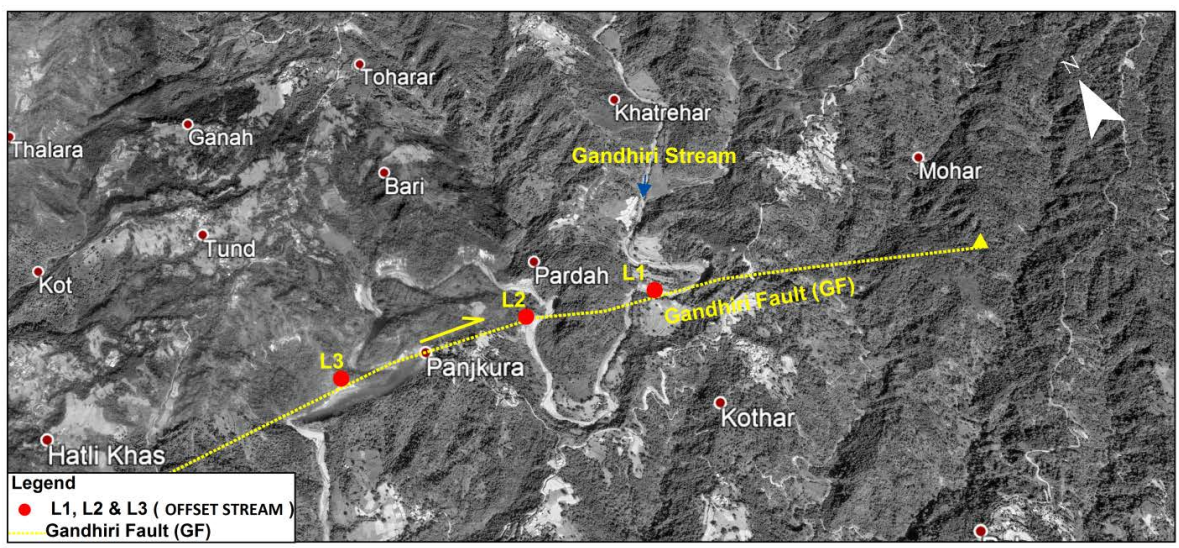

Figure 3. Google Earth satellite imagery showing the true colour 3-D image and location of the investigated stream in relation to nearby localities.
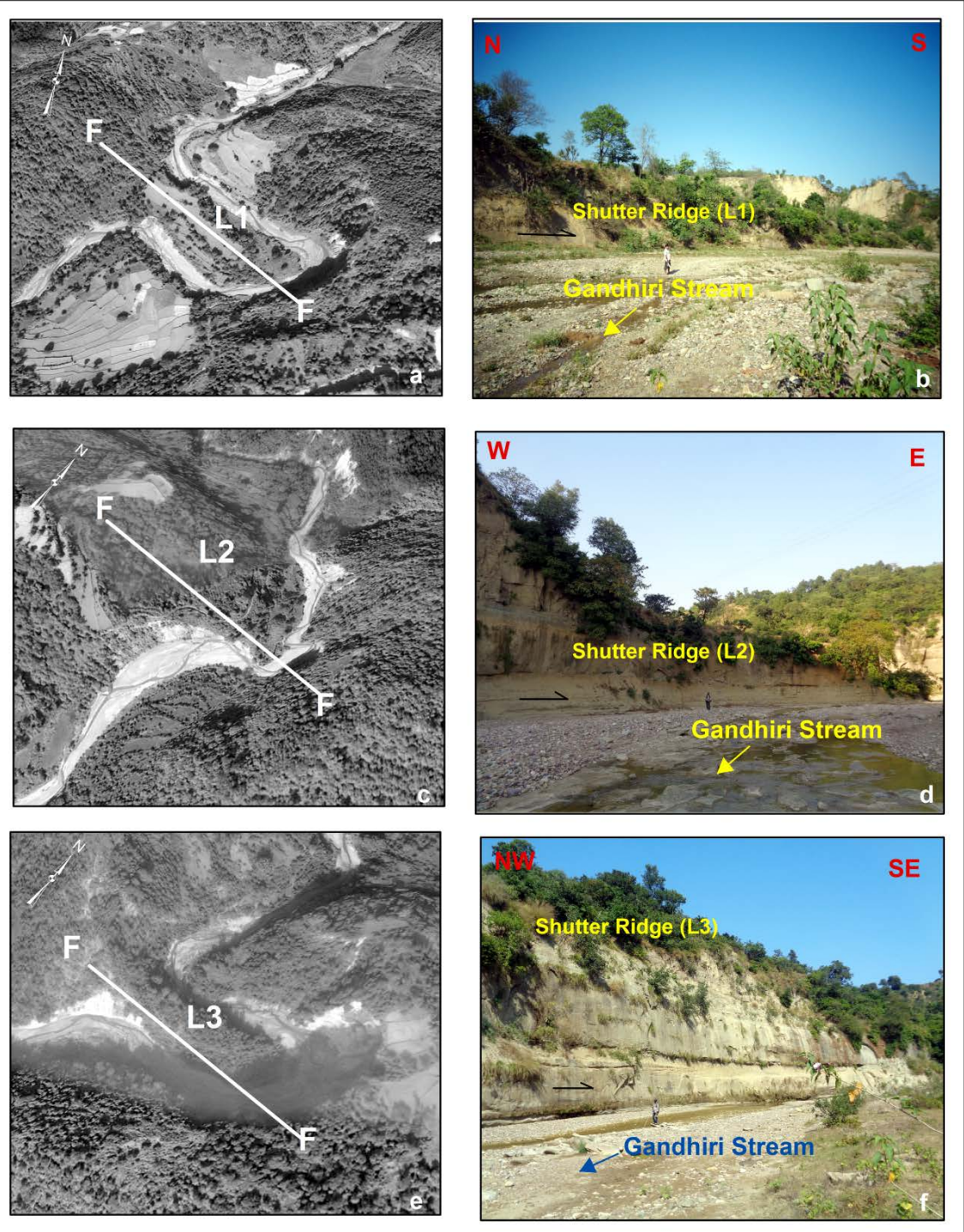

Figure 4. (a, c, e) The shutter ridges L1, L2 and L3; (b, d, f) field photographs of the corresponding shutter ridges. 
These three shutter ridges are 4 to $7 \mathrm{~m}$ in height and $158 \mathrm{~m}, 111 \mathrm{~m}$ and $108 \mathrm{~m}$ in length. In order to comprehend the active tectonic nature of the structural element, the different morphotectonic indices have evaluated. Shuttle Radar Topographic Mission based digital elevation model is being used to extract the drainage of the Gandhiri stream and the Duhg stream. These stream exhibits parallel drainage pattern. Hydro tool of ArcGIS is used to extract sub-drainage basins of the Gandhiri stream. The five sub-drainage basins have been identified (Figure 5). The characteristics of the various morphotectonic indices of the five sub-drainage basins are described here. Highly dissected hills of Middle Siwalik subgroup consisting of vertical scarp faces about $5 \mathrm{~m}$ in height are frequently observed. The drainage pattern has been extracted from Shuttle Radar Topography Mission based digital elevation model and compared with standard drainage pattern (Figure 6). Parallel Gandhiri stream and Duhg stream show parallel drainage pattern.

\section{Morphotectonic Evidence of the Gandhiri Fault}

\subsection{Hypsometric Curve and Integral (HI)}

Hypsometric analysis expresses the relative area distribution from one drainage basin to the surrounding terrain [19]. Hypsometric integral was calculated for each sub-drainage basin. The curves related to 5 sub-drainage basins have been plotted between relative area and relative height (Figure 7). The degree of convexity and concavity of the curve is used to differentiate between younger and the mature landscapes. The calculation procedure used is

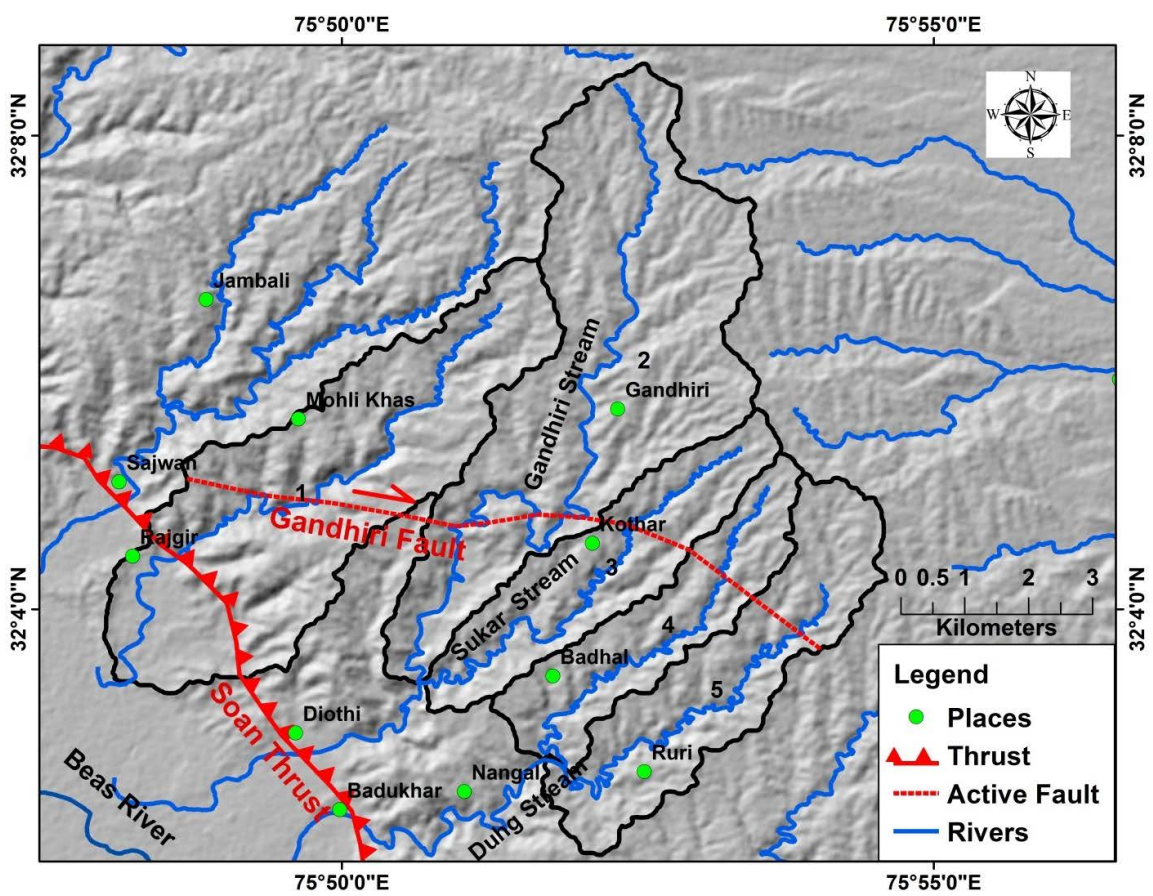

Figure 5. Sub-drainage basin map of Gandhiri stream showing the orientation of Gandhiri Fault. 


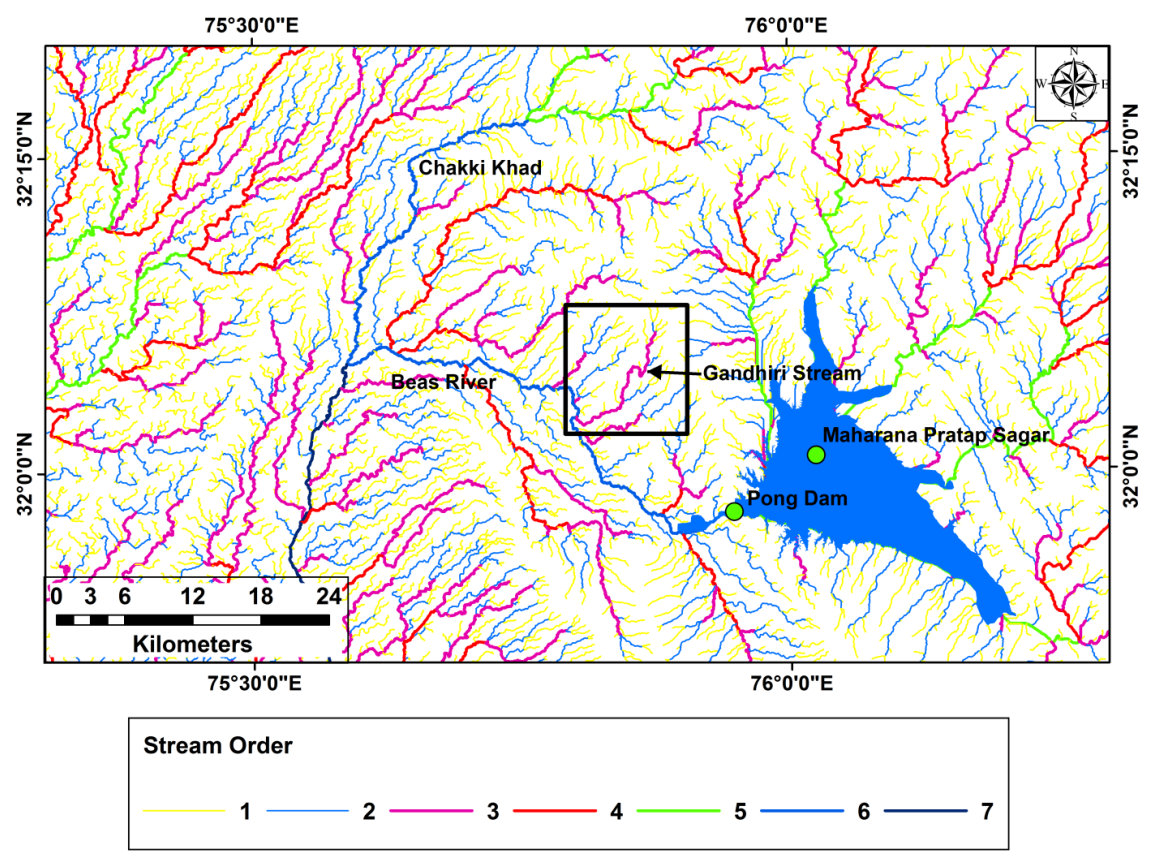

Figure 6. Drainage map of the study area.
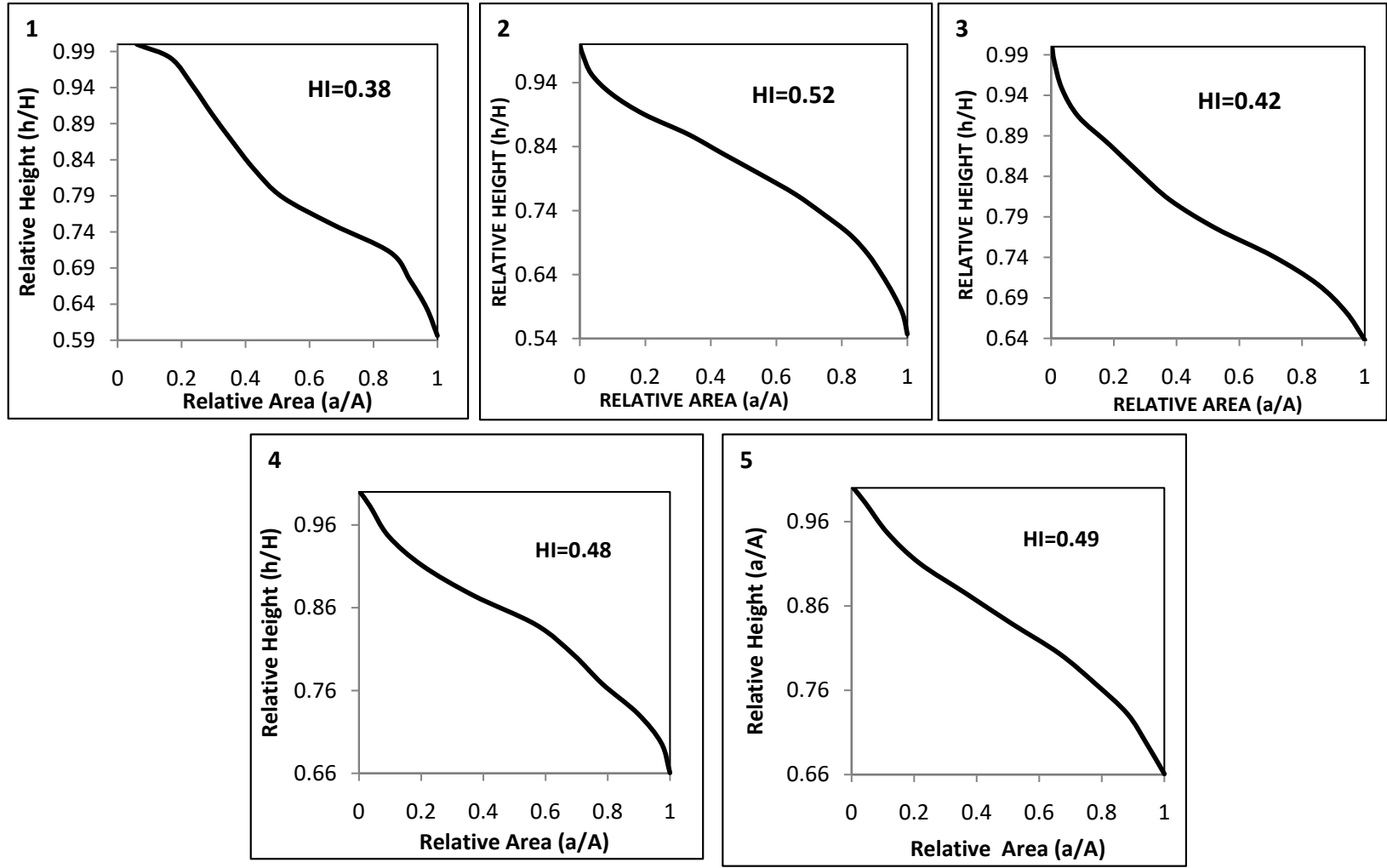

Figure 7. Hypsometric curve of the sub-drainage basins of the Gandhiri stream.

$$
\begin{gathered}
\mathrm{HI}=(\text { Mean elevation - Minimum elevation)/ } \\
\text { (Maximum elevation - Minimum elevation) }
\end{gathered}
$$

The hypsometric curve has been prepared by data extracted from digital ele- 
vation model of each sub-drainage basin. The raster layer of each sub-drainage basins has been reclassified with an equal elevation interval. The range of hypsometric integral value varies from 0.38 to 0.52 . Different classes have been assigned to the sub-drainage basins after the evaluation of hypsometric integral such as, convex shaped curve-highly active $(>0.45)$; convex to concave shaped curve-moderately active $(0.3-0.45)$ and concave shaped curve-slightly active $(<0.3)$. All sub-drainage basins lie in Class 1 and Class 2, which reveals their youthful stage and that the possibility of active faulting is present in this region (Table 2).

\subsection{Drainage Basin Asymmetry (AF)}

Asymmetry factor is a successful parameter for evaluating the active tectonic tilting in basins in the possible seismic potential zone by envisioning neotectonic structures [24] [46]. The asymmetry factor (AF) can distinguish tilting on basin scales and is sensitive to tilting in directions opposite to the course of the main channel [18]. It can also distinguish tectonic tilting of small scale basin or on mega scale. The asymmetry factor (AF) is related to the trends of the main channel and is sensitive to both the sides of the basin. A scenario in which the left or right side of the basin has larger tributaries than the opposite side indicates the tectonically rising of that segment. In such a case, the tributaries do headward erosion, and lengthening of channel takes place.

It is calculated by the formula:

$$
\mathrm{AF}=100\left(A_{r} / A_{t}\right)
$$

where, $A_{r}$ is the Area of the right side of sub-drainage basin (towards downstream) and $A_{t}$ represents the basin area. AF values vary from 42.74 to 55.70. These were grouped into three classes: Class $1(>10)$, Class 2 (5 to 10) and Class $3(<5)$ as shown in Table 3.

The results indicate that the five sub-drainage basins of the Gandhiri stream are tilted towards East. The first sub-drainage basin exhibits the highest order of tilting.

\subsection{Stream Length Gradient Index (SL)}

Stream Length Gradient Index (SL) [17] reveals the gradient anomaly in channel

Table 2. Calculation of hypsometric integral (HI) of different sub-drainage basins of the Gandhiri stream.

\begin{tabular}{|c|c|c|c|c|c|}
\hline $\begin{array}{l}\text { Sub-drainage } \\
\text { basins }\end{array}$ & Mean Elevation (m) & Max. Elevation (m) & Min. Elevation (m) & $\mathrm{HI}$ & Class \\
\hline 1 & 335.71 & 496.67 & 234.79 & 0.38 & 2 \\
\hline 2 & 457.18 & 602.03 & 295.05 & 0.52 & 1 \\
\hline 3 & 402.38 & 545.68 & 295.05 & 0.42 & 2 \\
\hline 4 & 412.16 & 521.65 & 308.05 & 0.48 & 1 \\
\hline 5 & 414.78 & 524.66 & 305.05 & 0.49 & 1 \\
\hline
\end{tabular}


Table 3. Calculation of drainage basin asymmetry factor (AF) of 5 sub-drainage basins of the Gandhiri stream.

\begin{tabular}{ccccc}
\hline Sub-drainage basins & $\boldsymbol{A}_{\boldsymbol{r}}\left(\mathrm{km}^{2}\right)$ & $\boldsymbol{A}_{\boldsymbol{t}}\left(\mathrm{km}^{2}\right)$ & $\mathrm{AF}$ & Class \\
\hline 1 & 7.16 & 16.75 & 42.74 & 2 \\
2 & 9.53 & 19.96 & 47.74 & 3 \\
3 & 3.49 & 07.01 & 49.78 & 3 \\
4 & 3.37 & 6.05 & 55.70 & 2 \\
5 & 4.06 & 8.52 & 47.65 & 3 \\
\hline
\end{tabular}

slope caused by the tectonic deformations. The rock resistance, topography, and tectonic activity are mutually expressed in this index. In general, resistant rocks exhibit high values of stream length gradient index (SL) while soft and fragile rocks show lower stream length gradient index. In tectonically active regions, the values of stream length gradient index will be higher.

The stream length gradient index (SL) is quantitatively computed evaluated by the following formula:

$$
\mathrm{SL}=(\Delta H / \Delta L) \times L
$$

where $\Delta H / \Delta L$ is the gradient for the respective nick points, and $L$ is the length from the most extended reach to the midpoint of the nick points.

Each sub-drainage basin has significant channels that are divided into equal segments of $500 \mathrm{~m}$, and the stream length gradient index (SL) values are calculated for each segment using a digital elevation model, and its average value is taken for each sub-drainage basin for assigning the class relative to the tectonic activity. The average value of this index in the five sub-drainage basins ranges from 47.05 to 101.58. Different classes [3] have been assigned to sub-drainage basins: 1 (SL $\geq 100), 2(51 \leq \mathrm{SL}>100)$ and 3 ( $\mathrm{SL} \leq 50)$. This lineament crosses the Gandhiri stream at three locations, so the values of stream length gradient index (SL) along the nick point of Gandhiri Stream are 74, 0.28 and 132.5, which suggests that the segments (L1 \& L2) of Gandhiri Fault govern the strike slip movement along the Gandhiri stream. During field observation, well developed shutter ridges indicating active strike slip movement are observed in the sub-drainage basins. The distribution of stream length gradient index (SL) over the Gandhiri stream and their basins is depicted along the lineament (Figure 8). The variation in stream length gradient index (SL) reflects the tectonic activity. Stream profile along with the stream length gradient index (SL) has been plotted for evaluating the channel slope anomalies (Figures 9(a)-(e)). High peaks of stream length gradient index (SL) depict the steep gradient of the channel segment. The low peak may indicate the strike slip movement along the affected segments of the lineament.

\subsection{Mountain Front Sinuosity Index $\left(S_{m f}\right)$}

Mountain front sinuosity index depicts the resultant between two opposing forces, one which develops embayment in mountain front and the other which tends to produce a straight mountain fronts. A strong tectonic influence results 


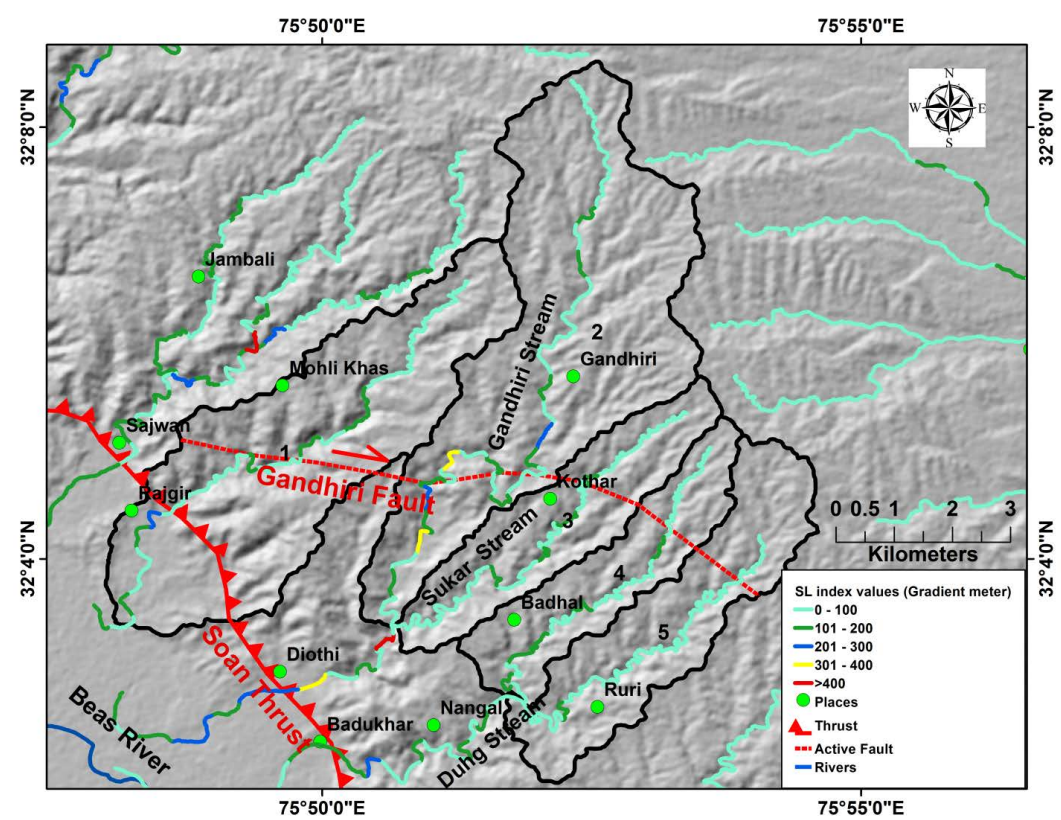

Figure 8. Distribution of stream length gradient index of sub-drainage basins of the Gandhiri stream.
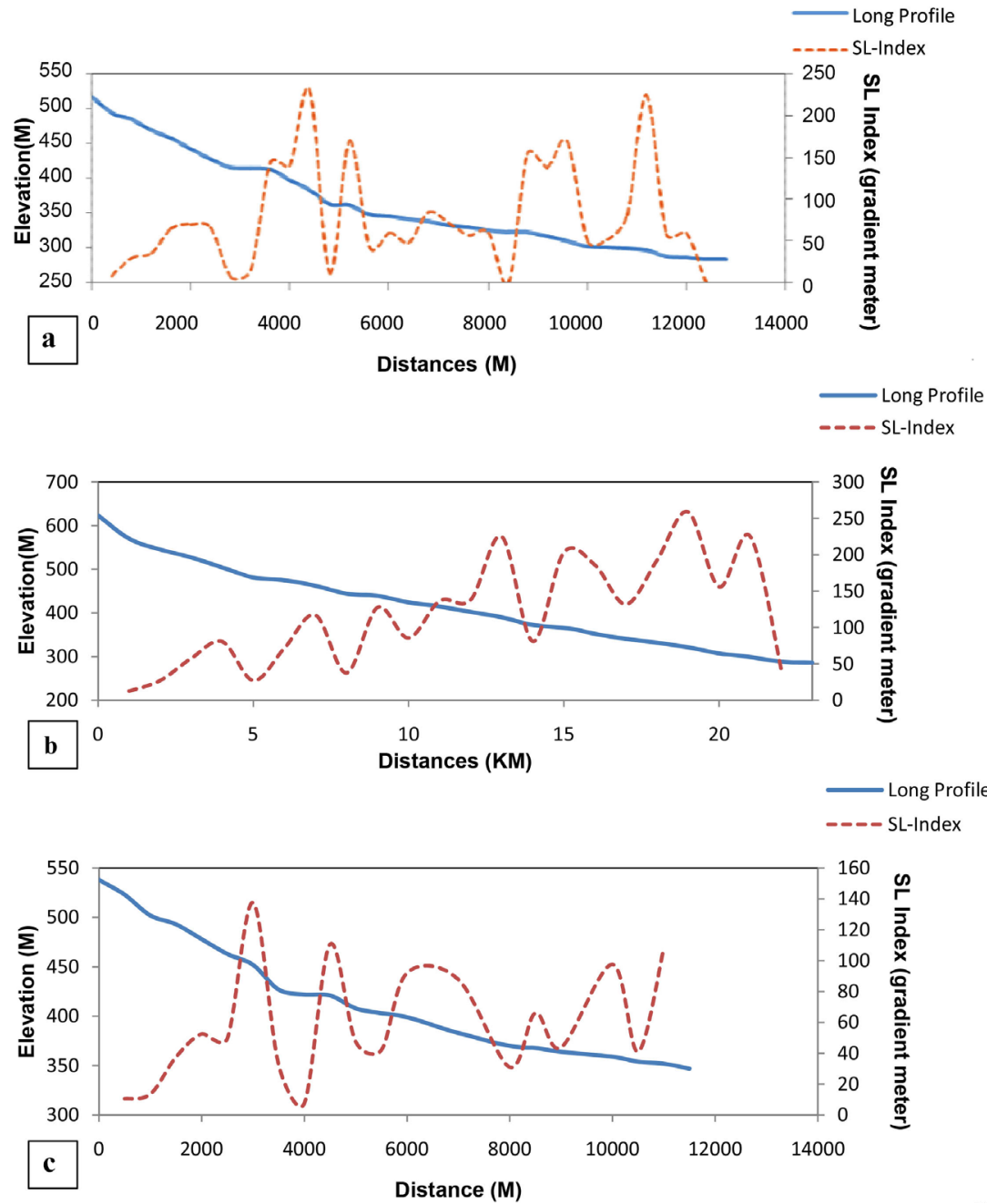


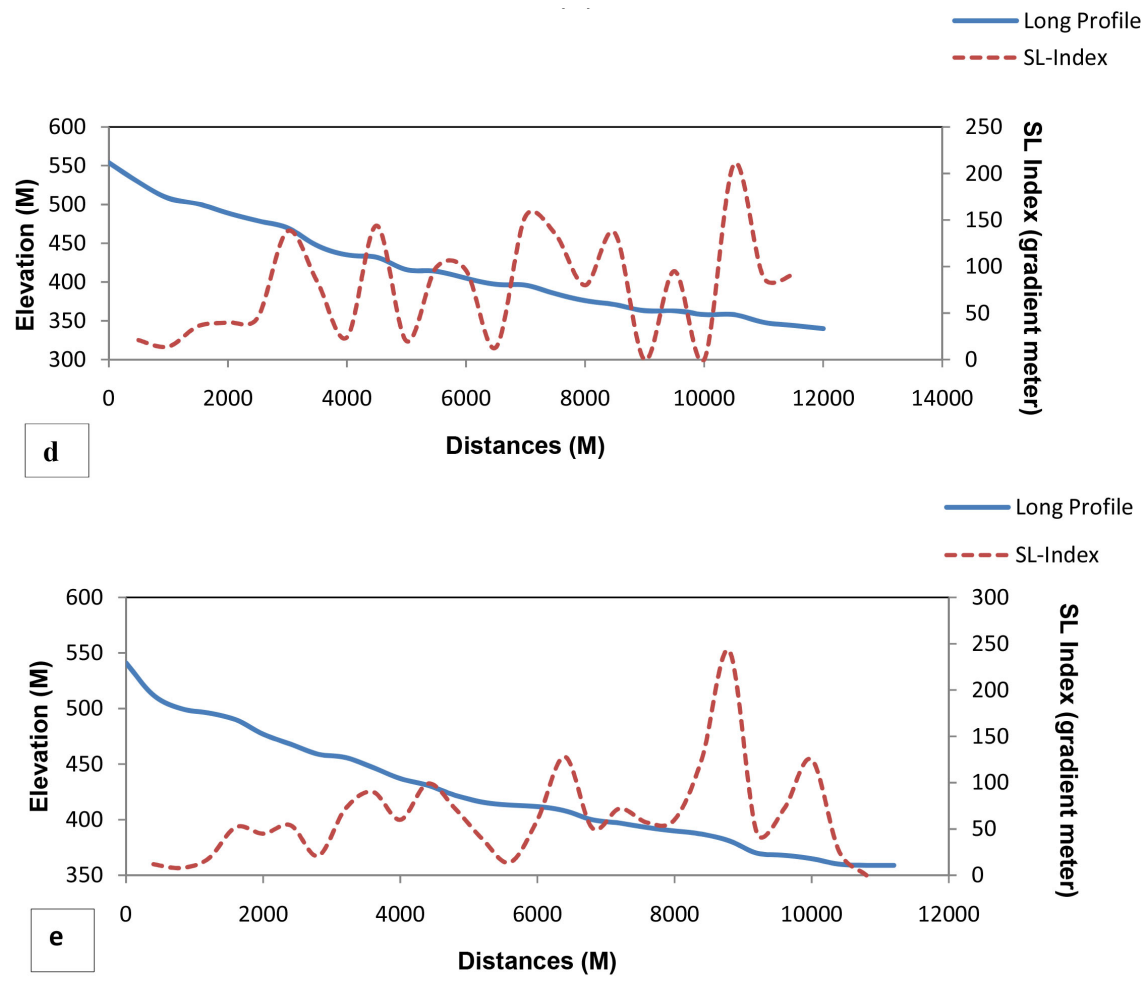

Figure 9. (a-e) Longitudinal profile-stream length gradient index (SL) Profile of sub-drainage basins of the Gandhiri stream.

in a straight active mountain front. Mountain front sinuosity is characterized as the proportion between the length of the mountain front along at its base $\left(L_{m f}\right)$ and the straight-line length of the entire mountain front $\left(L_{s}\right)$ [47]. The mountain front sinuosity $\left(S_{m f}\right)$ is computed as follows:

$$
S_{m f}=L_{m f} d L_{s}
$$

Along the lineament, mountain fronts have been examined for the estimation of mountain front sinuosity $\left(S_{m f}\right)$. Most of the Mountain fronts show the range of 1.0 to 1.2 (Table 4), which reveals the high upliftment rate of straight active mountain fronts with less erosional forces.

\subsection{Basin Shape Index $\left(B_{s}\right)$}

A circular basin shape represents tectonic stability while an elongation of the basin reflects the influence of tectonic forces which tend to alter the shape. The elongated shape of the drainage basin in the faulted region reflects the active tectonic settings [3] [20] [21].

The basin shape $\left(B_{s}\right)$ is calculated by the formula:

$$
B_{s}=B_{l} B_{W}
$$

where $B_{l}$ is the sub-drainage basins length taken from its outlet to the mouth, $B_{w}$ is the width at the widest points of the basin. In this study, $B_{s}$ is calculated from digital elevation model and it is divided into three classes: elongated shape $\left(B_{s} \geq\right.$ 4); semi-circular $\left(3 \leq B_{s}<4\right)$, and circular $\left(B_{s}<3\right)$, as shown in Table 5. 
Table 4. Mountain Front Sinuosity $\left(S_{m f}\right)$ calculated for the Gandhiri stream sub-drainage basin.

\begin{tabular}{ccccccc}
\hline \multicolumn{7}{c}{ Mountain Front Sinuosity $\left(S_{m f}\right)$} \\
\hline Sub-drainage basins & $S_{m f}$ No. & $L_{m f}(\mathrm{~m})$ & $L_{s}(\mathrm{~m})$ & $S_{m f}$ & Mean $S_{m f}$ Class \\
\hline 1 & 1 & 3024 & 2629 & 1.150 & 1.22 & 2 \\
2 & 2 & 987 & 756 & 1.30 & 1.05 & \\
2 & 3 & 218 & 206 & 1.20 & 1 \\
2 & 4 & 220 & 182 & 1.05 & & \\
\hline
\end{tabular}

Table 5. Drainage basin shape indices of sub-drainage basins of the Gandhiri stream.

\begin{tabular}{ccccc}
\hline Sub-drainage basins & $\boldsymbol{B}_{\boldsymbol{I}}(\mathrm{m})$ & $\boldsymbol{B}_{\boldsymbol{w}}(\mathrm{m})$ & $\boldsymbol{B}_{\boldsymbol{s}}$ & Class \\
\hline 1 & 9.89 & 2.88 & 3.4 & 2 \\
2 & 6.171 & 1.46 & 4.2 & 1 \\
3 & 8.59 & 3.04 & 2.8 & 3 \\
4 & 5.72 & 1.54 & 3.7 & 2 \\
5 & 6.73 & 1.64 & 4.1 & 1 \\
\hline
\end{tabular}

\subsection{Stream Sinuosity Index $(S)$}

Stream sinuosity is a delicate parameter that records tectonic changes in the landscape. Strike slip movement and tectonic uplift are recorded in stream sinuosity indices wherein streams modify their water velocity in conjunction with gradient modification. Stream sinuosity [48] [49] values were determined for those streams which cross the lineament and are apparently affected. The sinuosity values range from 1.28 to 1.44 , demonstrating their sinuous character (Channel sinuous if $S<1.5$ ) and presence of tectonically active terrain.

$$
S=\text { Channel length }(C) \text { /Valley length }(V)
$$

Sinuosity indicates a quantitative index of stream meandering and is a distinctive property of channel pattern. It relates to the morphological, sedimentological and hydraulic characteristics of stream channels. The results of the indices in different sub-drainage basins of the Gandhiri stream represents in Table 6.

\subsection{Valley Floor Width to Valley Height $\left(V_{f}\right)$ Ratio}

Valley floor width to valley height ratio $\left(V_{f}\right)[47]$ is a geomorphic index used to separate $V$ and $U$ shaped valleys. The $V$ shaped valley is formed by the high upliftment rate and maintenance of the equilibrium channel slope by a corresponding increase in incision rate of the channel. $U$ shaped valley develops due to side cutting erosion and processes of streams in relatively stable tectonic settings. However, the presence of strike slip fault changes the landscape of the valley and terraces rise as sediments accumulate.

$V_{f}$ value is calculated as:

$$
V_{f}=2 V_{f w} /\left[\left(E_{l d}-E_{s c}\right)+\left(E_{r d}-E_{s c}\right)\right]
$$


Table 6. Stream sinuosity $(S)$ indices of the Gandhiri stream.

\begin{tabular}{ccccc}
\hline Sub-drainage basin & $C(\mathrm{~km})$ & $V(\mathrm{~km})$ & $S$ & Class \\
\hline 1 & 8.72 & 6.56 & 1.32 & 1 \\
2 & 5.7 & 3.94 & 1.44 & 1 \\
3 & 2.69 & 2.1 & 1.28 & 1 \\
4 & 2.37 & 1.74 & 1.36 & 1 \\
5 & 1 & 0.74 & 1.35 & 1 \\
\hline
\end{tabular}

where " $V_{f w}$ " is the width of the valley floor; " $E_{l d}$ " and " $E_{r d}$ " are the rises of the left and right valley partitions individually, and " $E_{s c}$ " is the rise of the valley floor. Location of $V_{f}$ of the sub-drainage basins of the Gandhiri stream is shown in Figure 10. The range of $V_{f}$ for different sub-drainage basins of the Gandhiri stream vary from 0.16 to 0.94 . The $V_{f}$ values were grouped into three classes as Class $1(0.1-0.5)$, Class $2(0.5-1.0)$ and Class $3(1.0-1.1)$ as shown in Table 7. $V_{f}$ is generally low for $V$ shaped valleys, and high for $U$ shaped valleys. Low values of $V_{f}$ are related to higher tectonic activity. $V_{f}$ values of less than 1 are associated with direct dynamic down cutting streams, while $V_{f}$ values more than 1 suggest a flat or broad valleys ( $U$-shaped) with prominent side cutting erosion and relative tectonic stability.

\section{Field Investigations}

Field investigation carried out in the different sub-drainage basins of the Gandhiri stream reveals the presence of offset streams, shutter ridges, pressure ridges along the trace of the lineament which has been identified on the satellite imagery. The presence of offset streams, shutter ridges, pressure ridges and seismites like pear drop structures, flame structures, sand dykes and soft sediment deformation features reveals that significant displacement has taken place in a dextral manner (Figure 11(c)). This lineament represents a strike slip dextral fault with significant oblique slip component. It is being named as Gandhiri Fault after the Gandhiri stream. This Fault has a surface expression of $3.2 \mathrm{~km}$ and appears to have a significant hidden segment. The tectonic activity along this fault has resulted in progressive accumulation of stress (Figure 11(a), Figure 11(b)). Fault signature such as tilted trees have been observed along the shutter ridges (Figure 11(b)). The pear drop structures have developed as a consequence of tectonic movement. The values of tectonic morphometric indices support the presence of an active segmented dextral strike slip fault with significant oblique slip component. Perched terraces are well developed on Middle Siwalik sandstone at a height of more than four meter in the different sub-drainage basins of the Gandhiri stream (Figure 12).

\section{Discussion}

Geomorphic indices have been used for classifying faults into different tectonic 


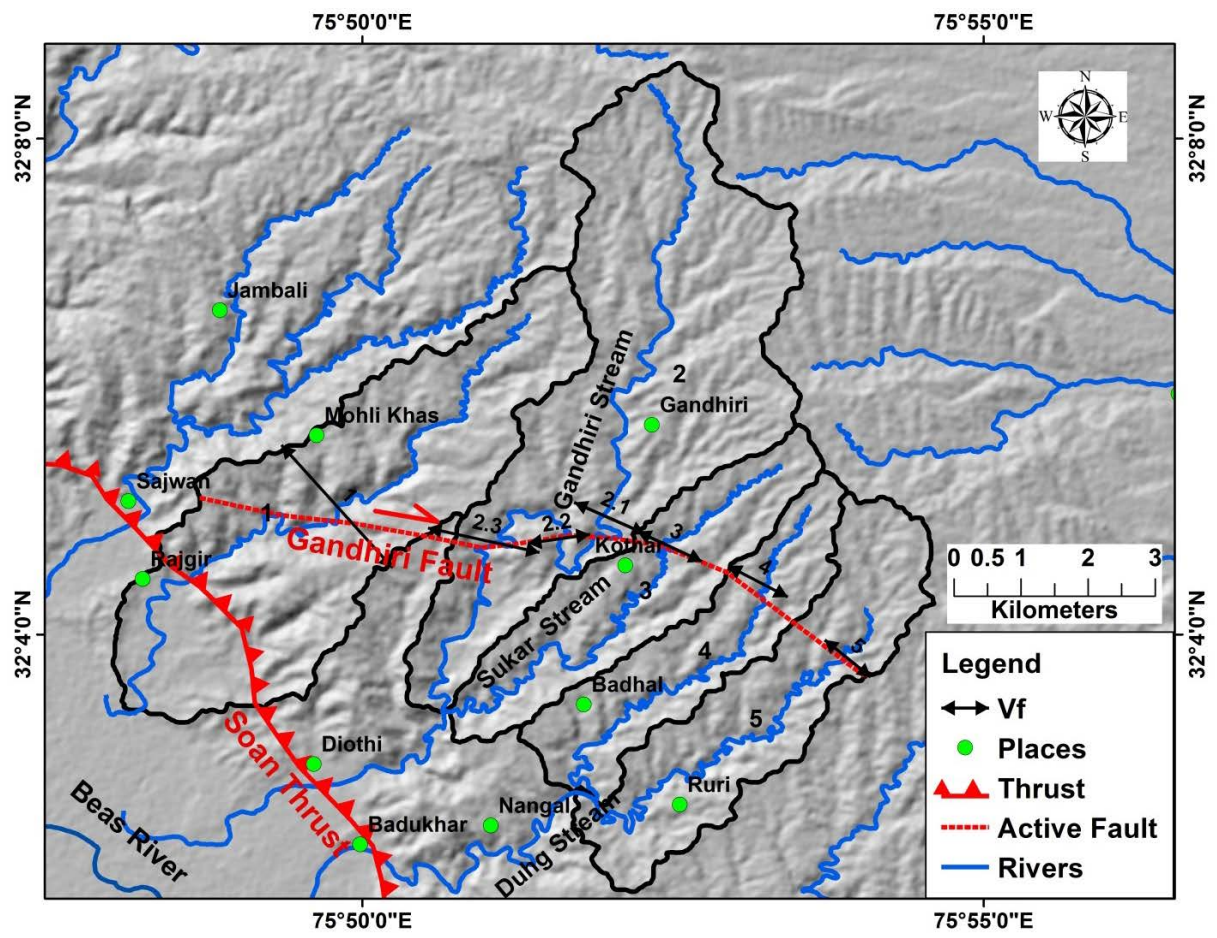

Figure 10. Location of $V_{f}$ of the sub-basins of the Gandhiri stream.

Table 7. Calculation of indices of valley floor width to valley height ratio ( $\left.V_{f}\right)$ for different sub drainage basins of the Gandhiri stream.

\begin{tabular}{ccccccccc}
\hline Sub-drainage basin & $V_{f}$ No. & $V_{f w}(\mathrm{~m})$ & $E_{I d}(\mathrm{~m})$ & $E_{r d}(\mathrm{~m})$ & $E_{s c}(\mathrm{~m})$ & $V_{f}$ & Mean $V_{f}$ & Class \\
\hline 1 & 1 & 20 & 440 & 469 & 345 & 0.182 & & 1 \\
2 & 2.1 & 18.07 & 461 & 478 & 434 & 0.509 & & \\
2 & 2.2 & 59.90 & 465 & 463 & 414 & 1.198 & 0.941 & 2 \\
2 & 2.3 & 91.00 & 458 & 469 & 382 & 1.116 & \\
3 & 3 & 13.66 & 479 & 481 & 431 & 0.278 & 1 \\
4 & 4 & 7.60 & 476 & 481 & 431 & 0.160 & 1 \\
5 & 5 & 8.20 & 499 & 502 & 457 & 0.188 & 1 \\
\hline
\end{tabular}

activity classes. The index of relative tectonic activity based on tectonomorphic indices like drainage basin asymmetry, hypsometry integral, valley floor width to valley height ratio, stream length gradient index, stream sinuosity index and mountain front sinuosity index have been used in the five sub drainage basin of the Gandhiri stream for the classification into different IRAT classes. Three classes (Table 8 ) have been designated for grouping the tectonic activity namely Class 1: very high tectonic activity; Class 2: moderate tectonic activity and Class 3: low tectonic activity. The $S / n$ values are worked out by calculating the mean of different geomorphic indices. IRAT Class 1 is having $S / n$ values $\leq 1.5$; Class 2 has $S / n$ values 1.51 to 1.70 and Class 3 has $S / n$ values $>1.70$. The sub-drainage basin 1 and 3 of the Gandhiri stream fall in IRAT Class 3, sub drainage basin 5 in Class 2 while sub-drainage basin 2 and 4 fall in most tectonically active classes. 


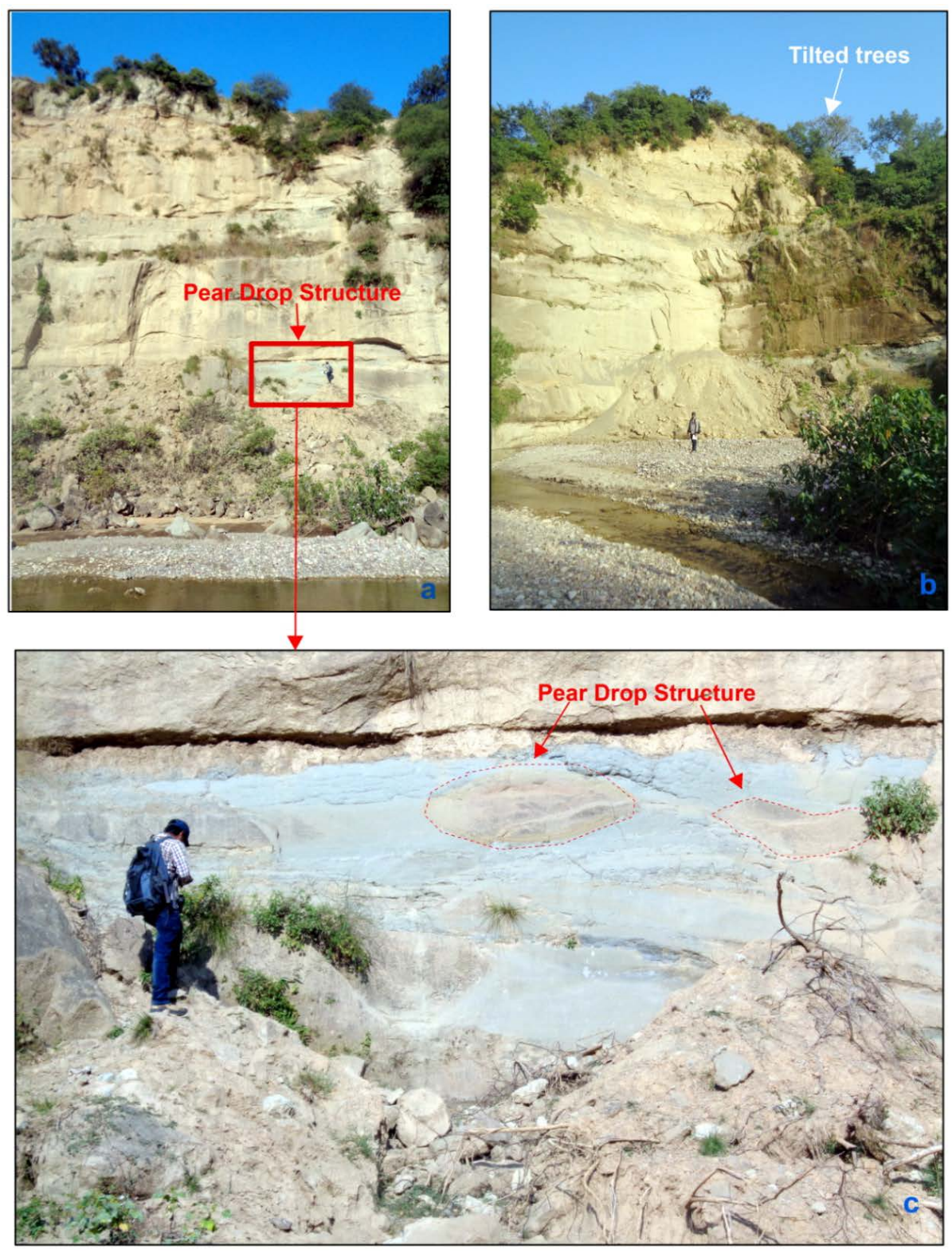

Figure 11. (a) Near vertical linear fault controlled hill face along the Gandhiri fault. The fault activity has resulted in a barren hill face; (b) Tilted trees along the active Gandhiri fault; (c) Seismite-Pear drop structures.

Table 8. Index of Relative Tectonic Activity (IRAT) calculated by the mean of all geomorphic indices $(S / n)$.

\begin{tabular}{cccccccccc}
\hline $\begin{array}{c}\text { Sub-drainage } \\
\text { basin No. }\end{array}$ & SL & AF & HI & $V_{f}$ & $B_{s}$ & $S_{m f}$ & $S$ & $S / n$ & $\begin{array}{c}\text { IRAT } \\
\text { Class }\end{array}$ \\
\hline 1 & 2 & 2 & 2 & 1 & 2 & 2 & 1 & 1.71 & 3 \\
2 & 1 & 3 & 1 & 2 & 1 & 1 & 1 & 1.42 & 1 \\
3 & 2 & 3 & 2 & 1 & 3 & - & 1 & 2.00 & 3 \\
4 & 2 & 2 & 1 & 1 & 2 & - & 1 & 1.50 & 1 \\
5 & 3 & 3 & 1 & 1 & 1 & - & 1 & 1.66 & 2 \\
\hline
\end{tabular}




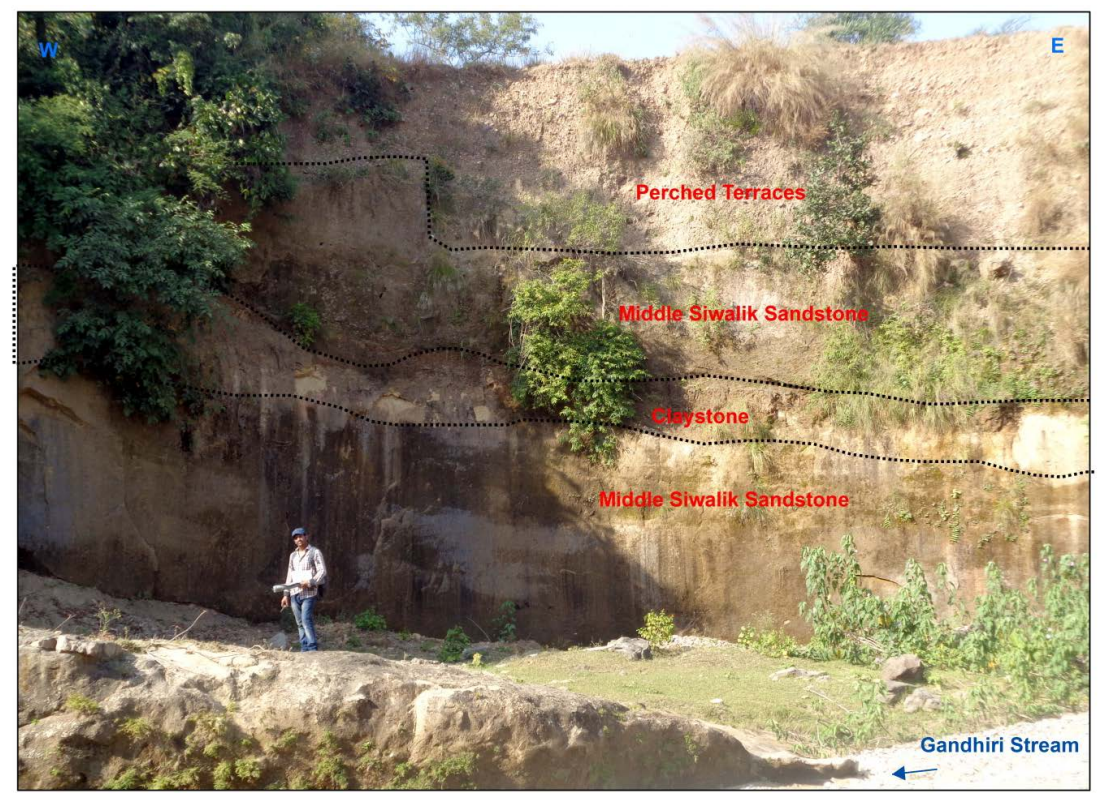

Figure 12. Perched terraces overlain on the Middle Siwalik subgroup in the Gandhiri stream sub-drainage basin 2 .

\section{Conclusion}

The present study has been carried out in the Kangra district of Himachal Pradesh where maximum damage was caused due to 1905 Kangra earthquake. Numerous scenario earthquake damage studies have been initiated to assess the present day possible damages in the event of large magnitude earthquake striking the region. The present study which attempts to fill in this gap regarding the seismo-tectonic character of the terrain in and around Gandhiri is significant. The results of the quantitative morphotectonic analysis reveal that the terrain is tectonically active and an active dextral strike slip fault which has been identified and named as the Gandhiri fault is a significant tectonic element. The index of relative tectonic activity reveals a very high activity for the sub-drainage basins 1 and 3 and relatively low tectonic activity for sub-drainage basin 2, 4 and 5. The data generated and the results thereof suggest that proper seismic codes be incorporated in all the planned constructions and retrofitting of the existing masonry structures.

\section{Acknowledgements}

The research work was carried out in Department of Geology, Kurukshetra University, Kurukshetra. The authors are thankful to scholars of the Sedimentology group namely Dr. Rajesh Ranga, Messer Vikram Sharma, Subhash, Veerendra Kumar Verma for their assistance in field and lab investigation. Yoginder Singh is thankful to UGC for providing Rajiv Gandhi National Fellowship.

\section{Conflicts of Interest}

The authors declare no conflicts of interest regarding the publication of this paper. 


\section{References}

[1] Bilham, R. (2001) Slow Tilt Reversal of the Lesser Himalaya between 1862 and 1992 at 78E, and Bounds to the Southeast Rupture of the 1905 Kangra Earthquake. Geophysical Journal International, 144, 1-23. https://doi.org/10.1046/j.1365-246x.2001.01365.x

[2] Rockwell, T.K., Keller, E.A. and Johnson, D.L. (1985) Tectonic Geomorphology of Alluvial Fans and Mountain Fronts near Ventura, California. In: Morisawa, M., Ed., Tectonic Geomorphology. Proceedings of the 15 th Annual Geomorphology Symposium, Allen and Unwin Publishers, Boston, 183-207.

[3] Ramirez-Herrera, M.T. (1998) Geomorphic Assessment of Active Tectonics in the Acambay Graben, Mexican Volcanic Belt. Earth Surface Processes and Landforms, 23, 317-332. https://doi.org/10.1002/(SICI)1096-9837(199804)23:4<317::AID-ESP845>3.0.CO;2-V

[4] Silva, P.G., Goy, J.L., Zazo, C. and Bardajm, T. (2003) Fault Generated Mountain Fronts in Southeast Spain: Geomorphologic Assessment of Tectonic and Earthquake Activity. Gemorphology, 250, 203-226.

https://doi.org/10.1016/S0169-555X(02)00215-5

[5] Molin, P., Pazzaglia, F.J. and Dramis, F. (2004) Geomorphic Expression of Active Tectonics in a Rapidly-Deforming Forearc, Sila Massif, Calabria, Southern Italy. American Journal of Science, 304, 559-589. https://doi.org/10.2475/ajs.304.7.559

[6] Chaudhri, A.R. (2005) Shutter Ridges and Sag Ponds along the Chandigarh Fault, Northwestern Himalaya. Department of Science \& Technology, Seismology Update, 1,6 .

[7] Chaudhri, A.R. (2007) Neotectonic Activities in the Himalayan Foothill Region-A Case Study. In: Varma, O.P., Mahajan, A.K. and Gupta, V., Eds., Natural Hazards, Indian Geological Congress, Roorkee, 73-83.

[8] Chaudhri, A.R. (2007) Seismo-Tectonic Characterization of the Himalayan Foothill Region-A Case Study. In: Saklani, P.S., Ed., Himalaya (Geological Aspects), Satish Serial Publishing House, New Delhi, Vol. 5, 41-50.

[9] Chaudhri, A.R. (2009) Soft Sediment Deformational Features (Seismites) as a Potential Tool for Seismic Hazard Assessment: A Case Study. Journal of Indian Association of Sedimentologists, 28, 49-53.

[10] Chaudhri, A.R. (2011) Assessing Tectonic Character the Terrain in the Frontal Siwalik Hills near Trilokpur, Northwestern Himalaya Using Remote Sensing and Tectonic Morphometric Approach. International Journal of Earth Sciences and Engineering, 4, 787-795.

[11] Chaudhri, A.R. (2012) Tectonic Morphometric Studies as a Tool for Terrain Characterization in the Himalayan Foothill Region: A Case Study. Journal Geological Society of India, 79, 210-218. https://doi.org/10.1007/s12594-012-0025-z

[12] El Hamdouni, R., Irigaray, C., Fernandez, T., Chacón, J. and Keller, E.A. (2008) Assessment of Relative Active Tectonics, Southwest Border of Sierra Nevada (Southern Spain). Geomorphology, 96, 150-173.

https://doi.org/10.1016/j.geomorph.2007.08.004

[13] Bagha, N., Arian, M., Ghorashi, M., Pourkermani, M., El Hamdouni, R. and Solgi, A. (2014) Evaluation of Relative Tectonic Activity in the Tehran Basin, Central Alborz, Northern Iran. Geomorphology, 213, 66-87. https://doi.org/10.1016/j.geomorph.2013.12.041

[14] Mahmood, S.A. and Gloaguen, R. (2012) Appraisal of Active Tectonics in Hindu 
Kush: Insights from DEM Derived Geomorphic Indices and Drainage Analysis. Geoscience Frontiers, 3, 407-428. https://doi.org/10.1016/j.gsf.2011.12.002

[15] Dehbozorgi, M., Pourkermani, M., Arian, M., Matkan, A.A., Motamedi, H. and Hosseiniasl, A. (2010) Quantitative Analysis of Relative Tectonic Activity in the Sarvestan Area, Central Zagros, Iran. Geomorphology, 121, 329-341. https://doi.org/10.1016/j.geomorph.2010.05.002

[16] Sharma, G., Champatiray, P.K. and Mohanty, S. (2018) Morphotectonic Analysis and GNSS Observations for Assessment of Relative Tectonic Activity in Alaknanda Basin of Garhwal Himalaya, India. Geomorphology, 301, 108-120. https://doi.org/10.1016/j.geomorph.2017.11.002

[17] Hack, J.T. (1973) Stream Profile Analysis and Stream Gradient Index. Journal of Research of the U.S. Geological Survey, 1, 421-429.

[18] Hare, P.W. and Gardner, T.W. (1985) Geomorphic Indicators of Vertical Neotectonism along Converging Plate Margins, Nicoya Peninsula, Costa Rica. In: Morisawa, M. and Hack, J.T., Eds., Tectonic Geomorphology. Proceedings of the 15th Annual Binghamton Geomorphology Symposium, Allen and Unwin, Boston, 123-134.

[19] Strahler, A.N. (1952) Hypsometric (Area-Altitude) Analysis of Erosional Topography. Geological Society of America Bulletin, 63, 1117-1142. https://doi.org/10.1130/0016-7606(1952)63[1117:HAAOET]2.0.CO;2

[20] Bull, W.B. and McFadden, L.D. (1977) Tectonic Geomorphology North and South of the Garlock Fault, California. In: Doehring, D.O., Ed., Geomorphology in Arid Regions. Proceedings of the Eighth Annual Geomorphology Symposium, State University of New York, Binghamton, 115-138.

[21] Canon, P.J. (1976) Generation of Explicit Parameter for a Quantitative Geomorphic Study of the Mill Creek Drainage Basin: Oklahoma. Geology Notes, 36, 3-18.

[22] Azor, A., Keller, E.A. and Yeats, R.S. (2002) Geomorphic Indicators of Active Fold Growth: Oak Ridge Anticline, Ventura Basin, Southern California. GSA Bulletin, 114, 745-753. https://doi.org/10.1130/0016-7606(2002)114<0745:GIOAFG>2.0.CO;2

[23] Keller, E.A. and Pinter, N. (1996) Active Tectonics: Earthquakes, Uplift, and Landscape. Prentice Hall, Upper Saddle River.

[24] Keller, E.A. and Pinter, N. (2002) Active Tectonics: Earthquakes, Uplift, and Landscape. 2nd Edition, Prentice Hall, Upper Saddle River.

[25] Gansser, A. (1964) The Geology of the Himalayas. Interscience, New York, 289.

[26] Molnar, P. and Tapponnier, P. (1975) Cenozoic Tectonics of Asia: Effects of a Continental Collision. Science, 189, 419-426. https://doi.org/10.1126/science.189.4201.419

[27] Visser, C.F. and Johnson, G.D. (1978) Tectonic Control of Late Pliocene Molasse Sedimentation in a Portion of the Jhelum Reentrant, Pakistan. Geologische Rundschau, 67, 15-37. https://doi.org/10.1007/BF01803254

[28] Burbank, D.W. and Raynolds, R.G.H. (1988) Stratigraphic Keys to the Timing of Deformation: An Example from the Northwestern Himalayan Foredeep. In: Paola, C. and Kleinspehn, K., Eds., New Perspectives in Basin Analysis, Springer-Verlag, New York, 331-351. https://doi.org/10.1007/978-1-4612-3788-4_17

[29] Meigs, A.J., Burbank, D.W. and Beck, R.A. (1995) Middle-Late Miocene (> $10 \mathrm{Ma}$ ) Formation of the Main Boundary Thrust in the Western Himalaya. Geology, 23, 423-426. https://doi.org/10.1130/0091-7613(1995)023<0423:MLMMFO>2.3.CO;2 
[30] Brozovic, N. and Burbank, D.W. (2000) Dynamic Fluvial Systems and Gravel Progradation in the Himalayan Foreland. Geological Society of America Bulletin, 112, 394-412. https://doi.org/10.1130/0016-7606(2000)112<394:DFSAGP >2.0.CO;2

[31] Dubey, A.K., Bhakuni, S.S. and Selokar, A.D. (2004) Structural Evolution of the Kangra Recess, Himachal Himalaya: A Model Based on Magnetic and Petrofabric Strains. Journal of Asian Earth Sciences, 24, 245-258. https://doi.org/10.1016/j.jseaes.2003.11.002

[32] Wobus, C., Heimsath, A., Whipple, K. and Hodges, K. (2005) Active Out-of-Sequence Thrust Faulting in the Central Nepalese Himalaya. Nature, 434, 1008-1011. https://doi.org/10.1038/nature03499

[33] Thakur, V.C., Joshi, M., Sahoo, D., Suresh, N., Jayangondapermal, R. and Singh, A. (2014) Partitioning of Convergence in Northwest Sub-Himalaya: Estimation of Late Qua-Ternary Uplift and Convergence Rates across the Kangra Reentrant, North India. International Journal of Earth Sciences, 103, 1037-1056. https://doi.org/10.1007/s00531-014-1016-7

[34] Malik, J.N., Sahoo, S., Satuluri, S. and Okumura, K. (2015) Active Fault and Paleoseismic Studies in Kangra Valley: Evidence of Surface Rupture of a Great Himalayan 1905 Kangra Earthquake (Mw 7.8), Northwest Himalaya, India. Bulletin of the Seismological Society of America, 105, 2325-2342. https://doi.org/10.1785/0120140304

[35] Joshi, M. and Thakur, V.C. (2016) Signatures of 1905 Kangra and 1555 Kashmir Earthquakes in Medieval Period Temples of Chamba Region, Northwest Himalaya. Seismological Research Letters, 87, 1150-1160. https://doi.org/10.1785/0220160033

[36] Cortés-Aranda, J., Vassallo, R., Jomard, H., Pousse-Beltrán, L., Astudillo, L., Mugnier, J.L., Jouanne, F., Malik, M. and Carcaillet, J. (2018) Late Quaternary Out-ofSequence Deformation in the Innermost Kangra Reentrant, NW Himalaya of India: Seismic Potential Appraisal from ${ }^{10} \mathrm{Be}$ Dated Fluvial Terraces. Journal of Asian Earth Sciences. https://doi.org/10.1016/j.jseaes.2018.01.027

[37] Chaudhri, R.S. (1991) Sedimentation Model of the Cenozoic Sediments of the Himalaya. Centre of Advanced Study in Geology, Panjab University, Vol. 4, 1-32.

[38] Chaudhri, R.S. (2000) Geology of the Siwalik Group of Western and Central Himalaya In: Mittal, S.P., Aggarwal, R.K. and Samra, J.S., Eds., Fifty Years of Research on Sustainable Resource Management in Siwalik, Publication Central Soil and Water Conservation Research and Training Institute, Chandigarh, 3-18.

[39] Powers, P.M., Lillie, R.J. and Yeats, R.S. (1998) Structure and Shortening of the Kangra and Dehra Dun Reentrants, Sub-Himalaya, India. Geological Society of America Bulletin, 110, 1010-1027. https://doi.org/10.1130/0016-7606(1998)110<1010:SASOTK>2.3.CO;2

[40] Delcaillau, B., Carroza, J.M. and Laville, E. (2006) Recent Fold Growth and Drainage Development: The Janauri and Chandigarh Anticlines in the Siwalik Foothills, Northwest India. Geomorphology, 76, 241-256. https://doi.org/10.1016/j.geomorph.2005.11.005

[41] Powers, P.M. (1996) Structure and Shortening of the Kangra and Dehra Dun Reentrants, Sub-Himalaya, India. Master's Thesis, Oregon State University, Corvallis.

[42] GSI (1995) Geological Quadrangle Map of Himachal Pradesh, Jammu and Kashmir and Punjab. Printing Division, Geological Survey of India, Hyderabad.

[43] Raiverman, V., Srivastava, A.K. and Prasad, D.N. (1993) On the Foothill Thrust of Northwestern Himalaya. Journal of Himalayan Geology, 4, 237-256.

[44] Ranga Rao, A. (1986) North-West Himalayan Foothills: Its Stratigraphical Record 
and Tectonic Phases. Bulletin ONGC, 23, 107-128.

[45] GSI and NRSC (2010) Manual for National Geomorphological and Lineament Mapping on 1:50,000 Scale (Document Control Number: NRSC-RS\&GISAA-ERGG\&GD-FEB’ 10-TR149). National Remote Sensing Centre, Hyderabad.

[46] Cox, R.T. (1994) Analysis of Drainage-Basin Symmetry as a Rapid Technique to Identify Areas of Possible Quaternary Tilt-Block Tectonics: An Example from the Mississippi Embayment. Geological Society of America Bulletin, 106, 571-581. https://doi.org/10.1130/0016-7606(1994)106<0571:AODBSA >2.3.CO;2

[47] Bull, W.B. (1977) Tectonic Geomorphology of the Mojave Desert, USGS Contract Report 14-08-001-G-394. Office of Earthquakes, Volcanoes and Engineering, Menlo Park.

[48] Mueller, J.E. (1968) An Introduction to the Hydraulic and Topographic Sinuosity Indexes. Annals of the American Association of Geographers, 58, 371-385. https://doi.org/10.1111/j.1467-8306.1968.tb00650.x

[49] Gomez, B. and Marron, D.C. (1991) Neotectonic Effects on Sinuosity and Channel Migration, Belle Fourche River, Western South Dakota. Earth Surface Processes and Landforms, 16, 227-235. https://doi.org/10.1002/esp.3290160304 